\title{
EFFECT OF M-SAND AND GGBS ON STRENGTH AND COMPACTION CHARACTERISTICS OF ROLLER COMPACTED CONCRETE PAVEMENT (RCCP)
}

\author{
S.Krishna Rao ${ }^{1}$, P.Sravana ${ }^{2}$, T.Chandrasekhara Rao $^{3}$ \\ ${ }^{1}$ Research Scholar, Civil Engineering, JNTUH, Hyderabad, Telangana, India-500085, 09948035265, \\ snkrishnarao@gmail.com \\ ${ }^{2}$ Professor, Civil Engineering, JNTUH, Hyderabad, Telangana, India-500085, 09866053569, \\ sravana.jntu@gmail.com \\ ${ }^{3}$ Professor, DMSSVH College of Engineering, Machilipatnam. AP, India -521002, 09848276672, \\ hoshikonni@gmail.com
}

\begin{abstract}
Roller Compacted Concrete (RCC) is a new construction methodology than a construction material used for paving applications across the world. Manufactured Sand (M-Sand) is produced from stone crusher units contains considerable amounts of finer material of size less than $0.075 \mathrm{~mm}$ and more angular than river sand. M-Sand can be used as alternate material for River sand. In the present paper an investigation was done on the effect of $M$-Sand on the strength and compaction characteristics of RCC using GGBS as mineral admixture. The Mix design is done with soil compaction Principles and based on ACI 211.3R guidelines. Ordinary Portland cement was partially replaced with GGBS at 10\%, 20\%, 30\%, 40\%, 50\%, and $60 \%$ by weight. Compaction characteristics are analyzed using OMC and MDD curve. Variation of Optimum Moisture Content with increase in GGBS content is studied. The relationship between density and percent replacement of cement with GGBS is established. With increased levels of GGBS content caused the increase in Flexural, Compressive and split tensile Strength values at 28 days and 90 days of curing.
\end{abstract}

Keywords: Roller Compacted Concrete Pavement; Optimum Moisture Content; Maximum Dry Density; GGBS; M Sand; Flexural Strength.

\section{INTRODUCTION}

Roller compacted concrete pavement material is very stiff mixture and requires vibratory roller compaction and normal methods of compaction are not suitable to apply. There is an urgent need to use alternate materials to conserve ever depleting natural reserves in the construction of various structures. This will reduce the cost of construction, effective utilization of waste materials and maintains ecological balance. M-Sands are produced by crushing various rocks into a fine aggregate of more angularity with rough textured surface. In the production of M-Sand the finer particles of size less than $0.075 \mathrm{~mm}$ has been in the range of $5 \%$ to $20 \%$. The practice of using of M-sand in the production of cement concrete is to wash out to eliminate finer particles[7]. Use of Mineral admixture in RCC production has been increased in the recent past. Atis[1] has investigated the effect of high volume fly ash on the strength and uses in pavement applications. Ganesh Babu K[2] proposed that with increase in fly ash content in RCC at high workability and with low cement content decreases the water cement ratio. Cheng, Cao et al [3], studied the effect of high volume fly ash an strength properties of RCC. Cement is replaced at $45 \%, 55 \%, 65 \%, 75 \%, 85 \%$ and $95 \%$ with fly ash and reported the increase in water contents from $106 \mathrm{~kg}$ to $133 \mathrm{~kg}$ per one $\mathrm{m}^{3}$ of concrete. Also the density of concrete is varying from $2526 \mathrm{~kg} / \mathrm{m}^{3}$ to $2581 \mathrm{~kg} / \mathrm{m}^{3}$ with varying properties of fly ash from $45 \%$ to $95 \%$. Luc Couraad et al [4] studied the effect of concrete road recycled aggregates for RCC production. They observed that $\mathrm{RCC}$ with natural and concrete road recycled aggregates are similar for solid compactness. The density of concrete used was varying between $2124-2229 \mathrm{~kg} / \mathrm{m}^{3}$ using recycled aggregates corresponding OMC are $5.54 \%$ to $7.85 \%$.

Rafat Sidique[5] Examined the effect of class F fly ash as fine aggregate replacement on the mechanical properties of concrete. He reported that with fine aggregate replacement by fly ash at $10 \%, 20 \%, 30 \%, 40 \%$ and $50 \%$ levels strengths are increased at all levels. Also the densities of mixture with fly ash varied from $2215 \mathrm{~kg} / \mathrm{m}^{3}$ to $2312 \mathrm{~kg} / \mathrm{m}^{3}$. Corresponding water content is varying from $185 \mathrm{~kg} / \mathrm{m}^{3}$ to $195 \mathrm{~kg} / \mathrm{m}^{3}$. M.Madhkhan et al[6] investigated the effect of pozzolans with steel and polypropylene fibres on mechanical properties of RCC pavements. For various mixtures used in the investigation the OMC varies from $5.05 \%$ to $6.03 \%$ and MDD varies between $2360 \mathrm{~kg} / \mathrm{m}^{3}$ to $2505 \mathrm{~kg} / \mathrm{m}^{3}$. The compressive strength decreased with addition of pozzolans at 28 days age. Also rupture modulus decreased.

Ganesh Babu K et al [8] studied the efficiency of GGBS in concrete. They replaced the cement with GGBS at $10 \%$ to $80 \%$ levels and found the possibility that the GGBS concrete 
can be designed for design strength at any given percentage of replacement. Karimpour.A [9] studied the effect of time span between mixing and compacting on roller compacted concrete with GGBS as mineral admixture. He found that delay in concrete compacting does not affect the properties with GGBFS and improved the compressive strength, permeability, absorption and adsorption. A.Oner et al [10] studied the optimum usage of GGBS in concrete and found that the compressive strength is increased with increase in GGBS content up to an optimum level of $55 \%$ and beyond this level the contribution of GGBS on strength is negligible.

From the detailed review of Literature it was concluded that an extensive research work was done on RCC with Fly ash as Mineral admixture. Little research was done on the compaction characteristics of RCC with GGBS as mineral admixture, and hence this experimental work is mainly focusing on strength and compaction behavior of GGBS roller compacted concrete with $\mathrm{M}$-sand as fine aggregate by replacing the river sand fully $(100 \%)$. Considering the Roller Compacting Concrete Materials as a particulate interacting material, standard soil mechanics methods can be employed to evaluate the properties of Roller Compacted Concrete Pavement (RCCP) with different volumes of GGBS. This is discussed in the present investigation.

\subsection{Objectives of the experimental work}

1. To Proportionate the RCC material for a specified flexural strength( $5 \mathrm{MPa}$ ) with $\mathrm{M}$-sand as fine aggregate

2. To study the effect of GGBS and M-sand on the Compaction Characteristics of RCC

3. To study the effect of GGBS and M-sand on strength properties of RCC.

\section{EXPERIMENTAL INVESTIGATIONS}

\subsection{Materials}

\subsubsection{Cement}

Ordinary Portland Cement OPC 53 Grade was used in the present experimental investigation. Physical Properties of cement were presented in Table 1. Cement was tested as IS 4031[12]

\begin{tabular}{|c|c|c|c|}
\hline $\begin{array}{l}\text { S. } \\
\text { No. }\end{array}$ & Test Property & Result & $\begin{array}{c}\text { Requirement } \\
\text { as per IS: } \\
12269- \\
2013[11]\end{array}$ \\
\hline 1 & $\begin{array}{l}\text { Fineness } \\
\text { (a) Sieve test } \\
\text { (b) Blaine }\end{array}$ & $\begin{array}{l}2 \% \\
285 \mathrm{~m}^{2} / \mathrm{kg}\end{array}$ & $\begin{array}{l}\text { a) }<10 \% \\
\text { b) }>225 \mathrm{~m}^{2} / \mathrm{kg}\end{array}$ \\
\hline 2 & Normal Consistency & $30.0 \%$ & - \\
\hline 3 & Specific Gravity & 3.15 & - \\
\hline 4 & Initial setting time & 105minutes & $>30 \mathrm{Min}$ \\
\hline 5 & Final setting time & 285minutes & $<600$ Min \\
\hline 6 & $\begin{array}{l}\text { Compressive strength } \\
\text { (a) 3days } \\
\text { (b) 7days } \\
\text { (c) 28days }\end{array}$ & $\begin{array}{l}29 \mathrm{~N} / \mathrm{mm}^{2} \\
40 \mathrm{~N} / \mathrm{mm}^{2} \\
58 \mathrm{~N} / \mathrm{mm}^{2}\end{array}$ & $\begin{array}{l}>27 \mathrm{~N} / \mathrm{mm}^{2} \\
>37 \mathrm{~N} / \mathrm{mm}^{2} \\
>53 \mathrm{~N} / \mathrm{mm}^{2}\end{array}$ \\
\hline
\end{tabular}

Manufactured sand(M-sand) was used as fine aggregate and was tested as per IS 383[13]. It was collected from V.N.S Ready Mix plant, Vijayawada, India. The specific gravity of M-sand was 2.713. Its particle size distribution was shown in Fig 1.

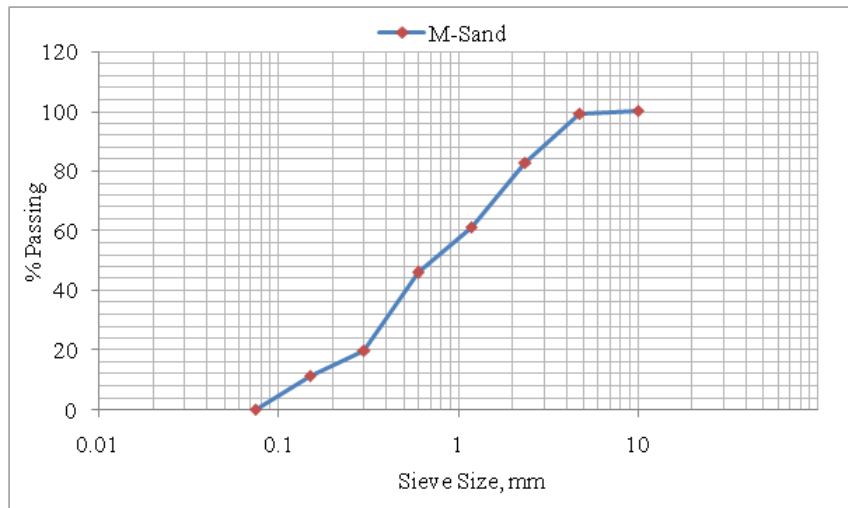

Figure.1 Particle Size Distribution Curve for M-sand

\subsubsection{Coarse Aggregate}

Crushed angular stone aggregate with NMSA of $19 \mathrm{~mm}$ and downgraded was used. Coarse aggregates passing $20 \mathrm{~mm}$ $10 \mathrm{~mm}$ and $6 \mathrm{~mm}$ sized were combined (40:40:20). The combined grading is given in Table.2 [14]. Particle size distribution curve is shown in Figure. 2

Table 2. Sieve Analysis of All in Aggregate

\begin{tabular}{|c|c|c|c|c|}
\hline Sieve Size & \multicolumn{4}{|c|}{ \% Passing } \\
\cline { 2 - 5 } & $\begin{array}{c}\text { M-sand } \\
\mathbf{( 4 0 \% )}\end{array}$ & $\begin{array}{c}\text { Combined } \\
\text { coarse } \\
\text { Aggregate } \\
(\mathbf{6 0 \%})\end{array}$ & $\begin{array}{c}\text { Combined } \\
\text { Grading }\end{array}$ & $\begin{array}{c}\text { As Per } \\
\text { ACI } \\
\mathbf{2 1 1 - 3 R}\end{array}$ \\
\hline $25 \mathrm{~mm}$ & 100 & 100 & 100 & 100 \\
\hline $19 \mathrm{~mm}$ & 100 & 100 & 100 & $82-100$ \\
\hline $12.5 \mathrm{~mm}$ & 100 & 88.8 & 93.28 & $72-93$ \\
\hline $9.5 \mathrm{~mm}$ & 100 & 65.94 & 79.56 & $66-85$ \\
\hline $4.75 \mathrm{~mm}$ & 99.30 & 33.78 & 59.98 & $51-69$ \\
\hline $2.36 \mathrm{~mm}$ & 82.70 & 14.76 & 41.93 & $38-56$ \\
\hline $1.18 \mathrm{~mm}$ & 61.15 & 7.02 & 28.67 & $28-46$ \\
\hline $0.600 \mathrm{~mm}$ & 45.90 & 4.86 & 21.27 & $18-36$ \\
\hline $0.300 \mathrm{~mm}$ & 19.85 & 2.62 & 9.51 & $11-27$ \\
\hline $0.150 \mathrm{~mm}$ & 11.40 & 0.98 & 5.14 & $6-18$ \\
\hline $0.075 \mathrm{~mm}$ & 2.60 & 0.12 & 1.11 & $2-18$ \\
\hline
\end{tabular}

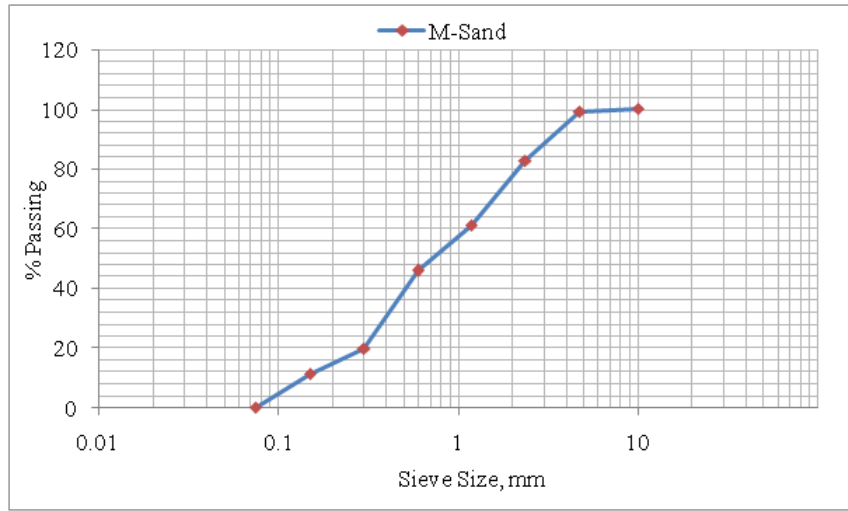

Fig.2. Particle Size Distribution curve of All in Aggregate

\subsubsection{Fine Aggregate:}




\subsubsection{Water:}

The water used in RCC mix design was potable and drinking water.

\subsubsection{Ground Granulated Blast furnace Slag}

\section{$(G G B S)$ :}

The GGBS used in this research project was collected from the TOSHALI CEMENTS PVT LTD located at Visakhapatnam District, Andhra Pradesh, India. The GGBS was ground in a laboratory mill to a Blaine fineness of 4222 $\mathrm{cm} 2 / \mathrm{g}$. The Physical properties of GGBS are given in Table 3.

Table 3: Physical Properties of GGBS and Cement

\begin{tabular}{|l|c|c|}
\hline Property & GGBS & Cement \\
\hline Specific gravity & 2.82 & 3.15 \\
\hline $\begin{array}{l}\text { Specific Surface } \\
\left(\mathrm{cm}^{2} / \mathrm{g}\right)\end{array}$ & 4222 & 2850 \\
\hline Color (Figure.3) & Whitish & Gray \\
\hline
\end{tabular}

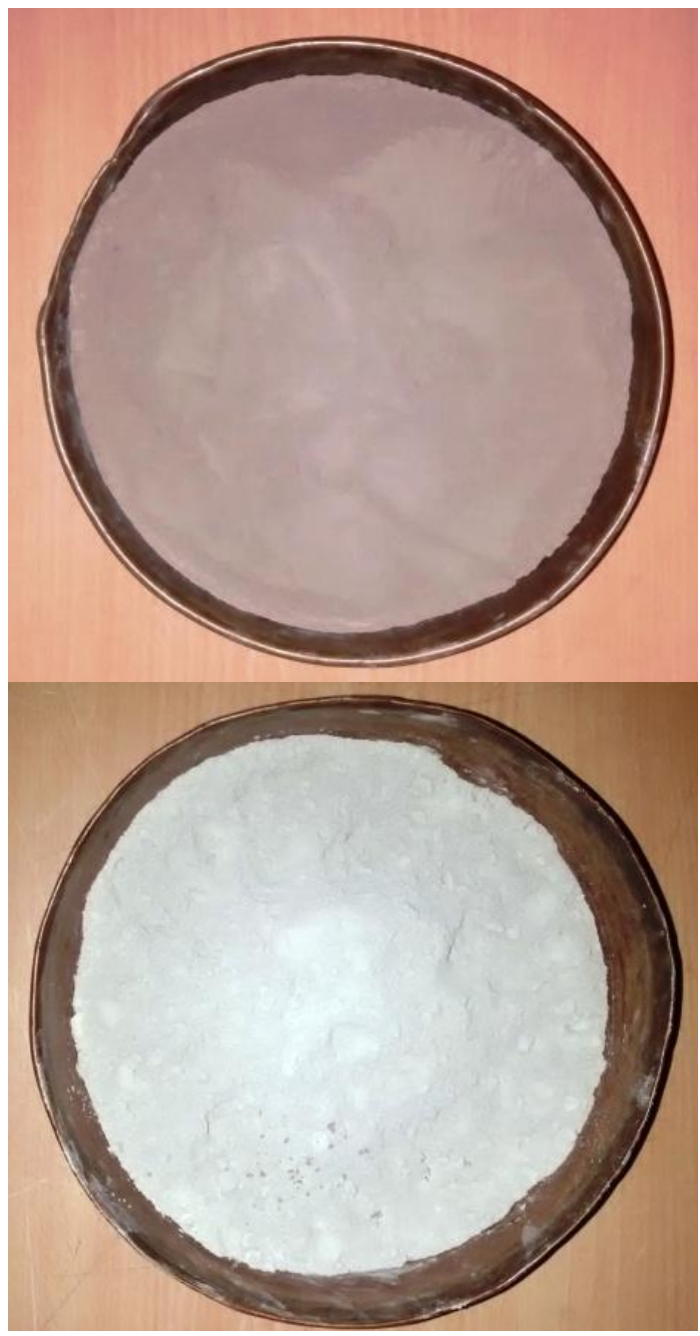

Figure 3. GGBS \& Cement

\section{METHODOLOGY:}

The Experimental work has been carried out in the following stages
Stage 1: Evaluation of Optimum Moisture Content of the RCC mixtures with M-sand as fine aggregate was considered. The OMC of Control mix Concrete and Mixtures containing GGBS as replacement of Cement were determined.

Stage 2: Evaluation of flexural, compressive and split tensile strength values at the ages of 3 days, 7 days, 28 days and 90 days was done in this stage.

\subsection{Determination of Optimum Moisture Content}

Mix design of RCC was done using ACI 211.3R-022004[14] specifications. The method was developed for RCC pavements of roads and is limited to mix design with maximum NMSA of $19 \mathrm{~mm}$ as per ACI 325.10R-95 [15]. The details of mixes are given in Table 6. The mix was proportioned for specified target flexural strength of $5.0 \mathrm{M}$ $\mathrm{Pa}[16,17,18,19]$. The Cement Content of control mix was $295 \mathrm{~kg} / \mathrm{m} 3$. Cement was replaced at $10 \%, 20 \%, 30 \%, 40 \%$, $50 \%$, and $60 \%$ by weight with GGBS. Using seven different water binder ratios seven mixture were prepared. 28 RCC mixtures were prepared using standard cylindrical specimens. For casting cylindrical specimens, split moulds of $15.0 \mathrm{~cm}$ diameter and $12.7 \mathrm{~cm}$ length, were used. This satisfies the IS: 2720 (Part 8) - 1983[20] standards for Modified compaction test. Casting was done before setting occurred. The whole mass of mix was compacted in 5 layers (Fig.4). After compaction of each layer, the top surface was scratched with a knife have good bonding with the next layer. A modified Proctor's rammer was used for this purpose in order to simulate field conditions. The type and other details of the rammer used are as mentioned in Table 4.

Table 4: Details of Rammer

\begin{tabular}{|l|l|l|}
\hline S. No & \multicolumn{2}{|c|}{ Details of Rammer } \\
\hline $\mathbf{1}$ & Rammer used & Modified Proctor type \\
\hline $\mathbf{2}$ & Weight & $4.90 \mathrm{~kg}$ \\
\hline $\mathbf{3}$ & Height of drop & $450 \mathrm{~mm}$ \\
\hline
\end{tabular}

To find the OMC of each mixture, representative samples were taken from the compacted specimens and kept in oven at 105 OC. The water content, wet density and dry density of each proposed mix were calculated using the following equations.

$\mathrm{w}=\frac{\left(\mathrm{w}_{\mathrm{w}}-\mathrm{w}_{\mathrm{d}}\right) 100}{\mathrm{w}_{\mathrm{d}}}$,

$\mathrm{w}$ is water content in $\% ; \mathrm{w}_{\mathrm{w}}=$ Weight of wet concrete $(\mathrm{g})$;

$\mathrm{w}_{\mathrm{d}}=$ Dry weight $(\mathrm{g})$

$$
\begin{aligned}
\gamma_{\text {wet }} & =\frac{\text { Weight of Wet concrete in kg }}{\text { Volume of Concrete } \mathrm{m}^{3}} \\
\gamma_{\text {dry }} & =\frac{\gamma_{\text {wet }}}{(1+w)}
\end{aligned}
$$




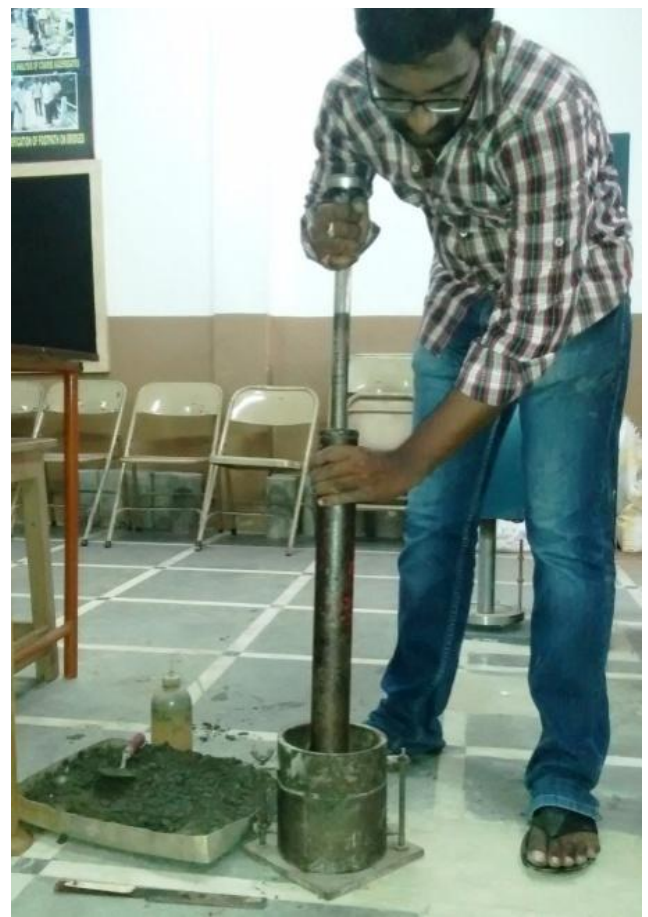

Figure.4 Compaction of RCC using modified Proctor's Rammer

The relationship between dry density and corresponding water contents were plotted for each mixture. From the moisture- density curve the optimum moisture content corresponding to the maximum dry density was determined and it is shown in Figures 5-13. And the results of the compaction test were given in Table 5 .

The mixture proportions of the RCCP are given in Table 5.

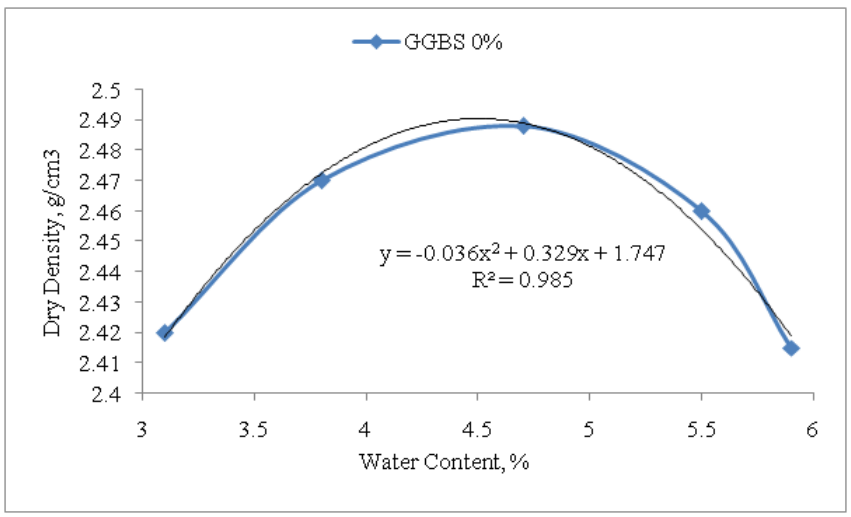

Figure.5 Relation between OMC and MDD of Control Mix

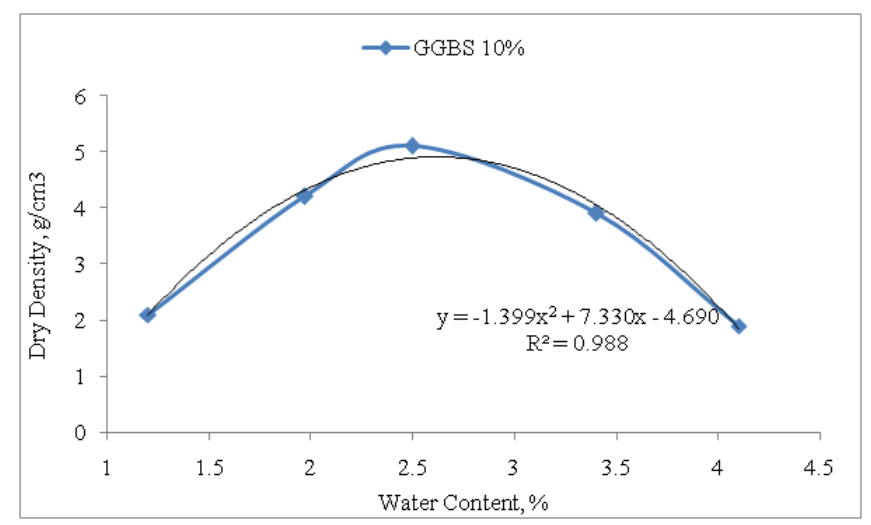

Figure.6 Relation between OMC and MDD for 10\% GGBS

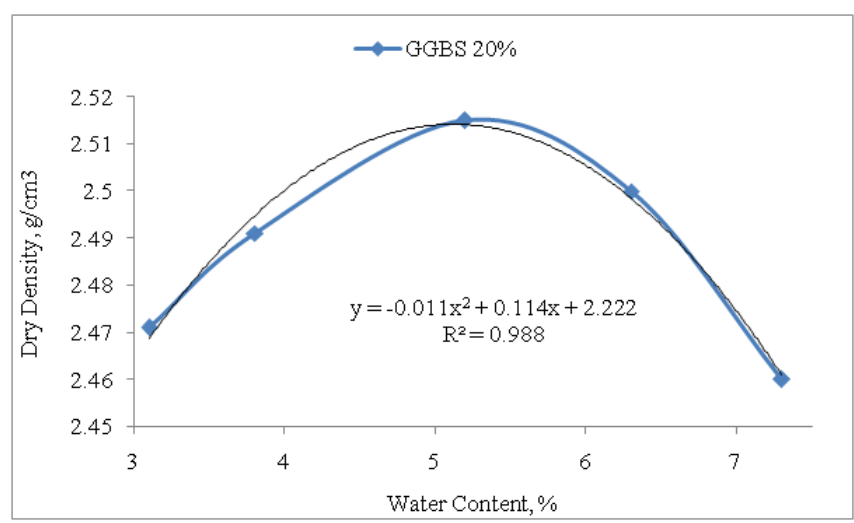

Figure.7 Relation between OMC and MDD for 20\% GGBS

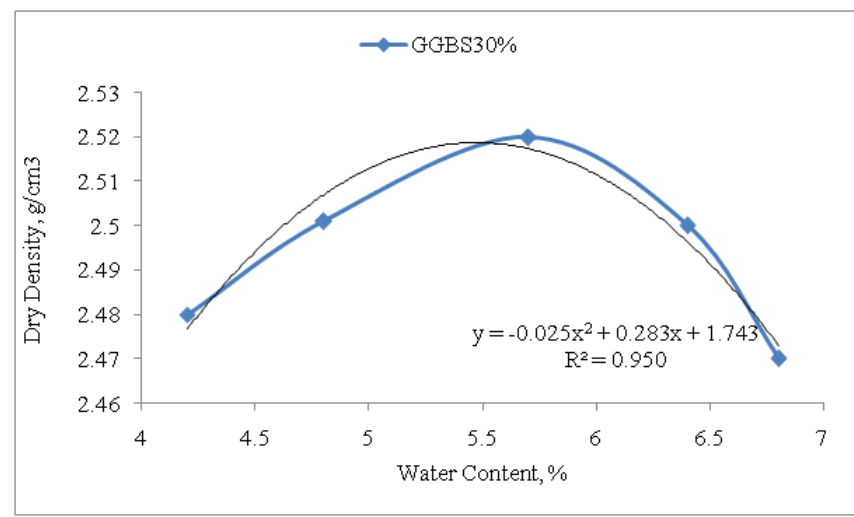

Figure.8 Relation between OMC and MDD for 30\% GGBS

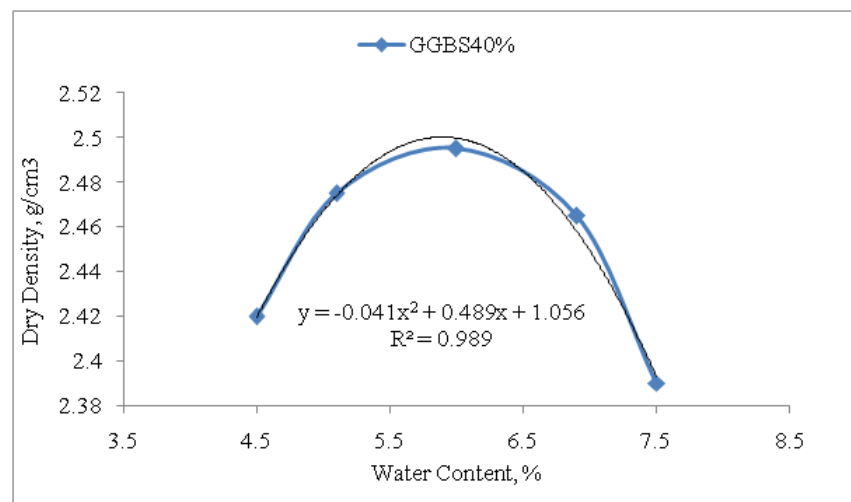

Figure.9 Relation between OMC and MDD for $40 \%$ GGBS

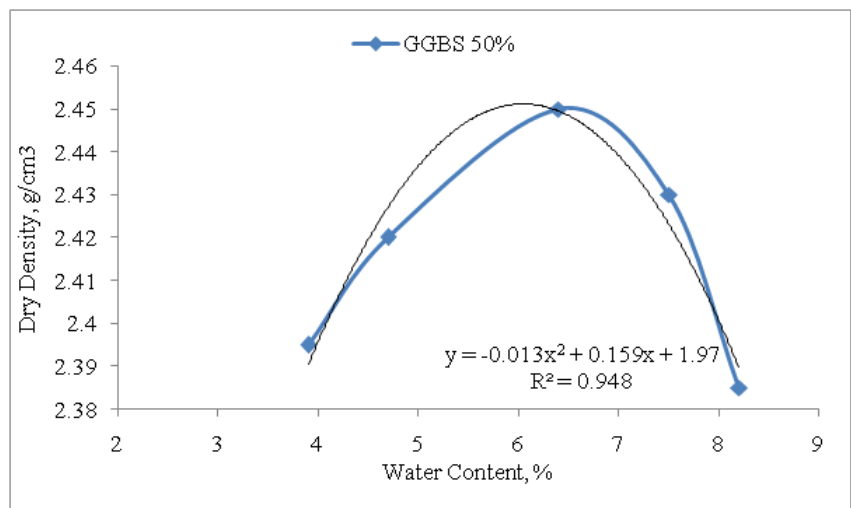

Figure.10 Relation between OMC and MDD for 50\% GGBS 


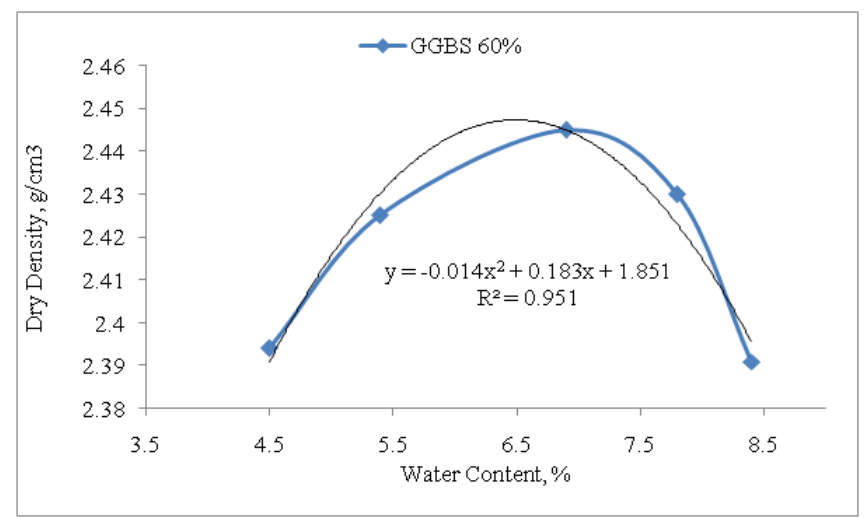

Figure.11 Relation between OMC and MDD for60\% GGBS

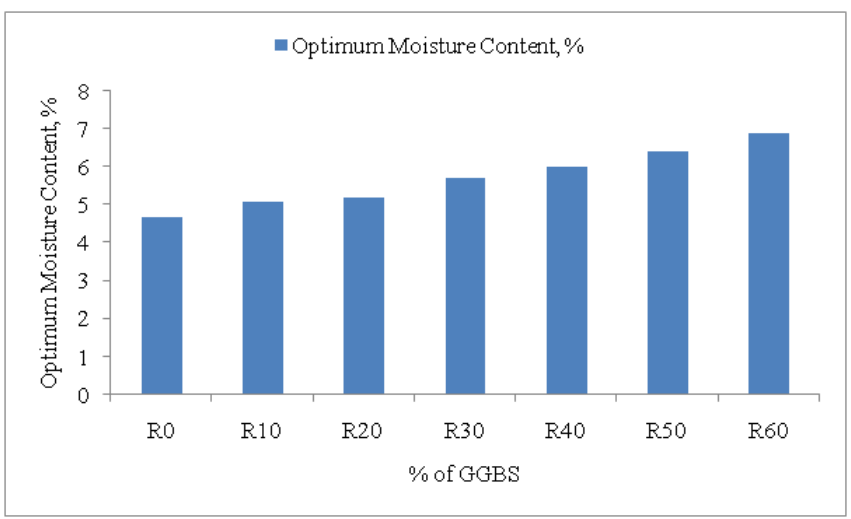

Figure.12 Relation between OMC and \% of GGBS
Table 6: OMC, MDD and w/b ratio of the Mixtures

\begin{tabular}{|c|c|c|c|c|}
\hline $\begin{array}{c}\text { Mixt } \\
\text { ure }\end{array}$ & $\begin{array}{c}\text { Optimum } \\
\text { Moisture } \\
\text { Content, } \\
\%\end{array}$ & $\begin{array}{c}\text { Maximum } \\
\text { Dry } \\
\text { Density, } \\
\mathrm{kg} / \mathrm{m}^{3}\end{array}$ & $\begin{array}{c}\text { Water, } \\
\mathrm{kg} / \mathrm{m}^{3}\end{array}$ & $\begin{array}{c}\text { Water Binder } \\
\text { Ratio }\end{array}$ \\
\hline R0 & 4.7 & 2.480 & 114 & 0.39 \\
\hline R10 & 5.1 & 2.495 & 117 & 0.39 \\
\hline R20 & 5.2 & 2.515 & 119 & 0.40 \\
\hline R30 & 5.7 & 2.520 & 126 & 0.43 \\
\hline R40 & 6.0 & 2.495 & 130 & 0.44 \\
\hline R50 & 6.4 & 2.450 & 147 & 0.51 \\
\hline R60 & 6.9 & 2.445 & 155 & 0.54 \\
\hline
\end{tabular}

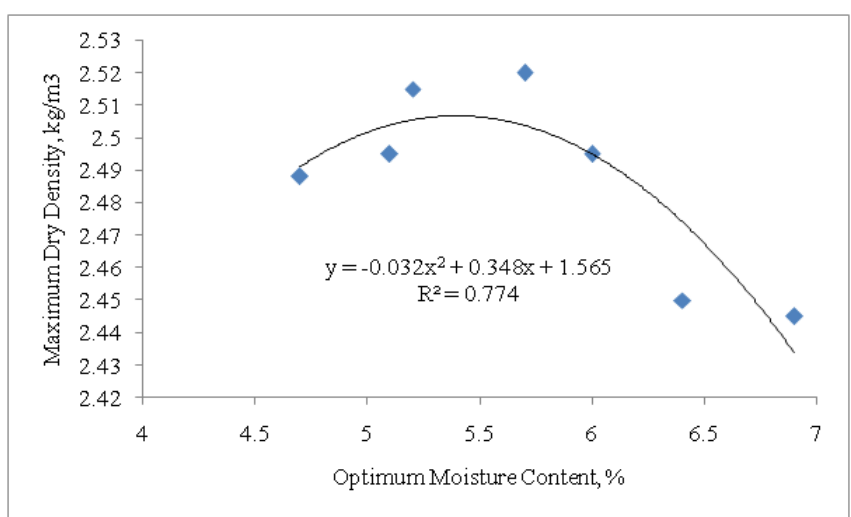

Figure.13 Relation between OMC and MDD

Table 6: Mix Proportions of RCCP Mixtures

\begin{tabular}{|c|c|c|c|c|c|c|}
\hline Mixture & $\begin{array}{c}\text { Cement } \\
( \\
\left.\mathrm{Kg} / \mathrm{m}^{3}\right)\end{array}$ & $\begin{array}{c}\mathrm{GGBS} \\
\left(\mathrm{Kg} / \mathrm{m}^{3}\right)\end{array}$ & $\begin{array}{c}\text { Fine } \\
\text { Aggregate, } \\
\mathrm{Kg} / \mathrm{m}^{3}\end{array}$ & $\begin{array}{c}\text { Coarse } \\
\text { Aggregate, } \\
\mathrm{Kg} / \mathrm{m}^{3}\end{array}$ & $\begin{array}{c}\text { Water, } \\
\mathrm{kg} / \mathrm{m} 3\end{array}$ & $\begin{array}{c}\text { Water } \\
\text { Binder } \\
\text { Ratio }\end{array}$ \\
\hline $\mathbf{R 0}$ & 295 & 0 & 801 & 1209 & 114 & 0.32 \\
\hline $\mathbf{R 1 0}$ & 265 & 30 & 822 & 1233 & 117 & 0.35 \\
\hline $\mathbf{R 2 0}$ & 235 & 60 & 820 & 1230 & 119 & 0.37 \\
\hline $\mathbf{R 3 0}$ & 205 & 90 & 813 & 1220 & 126 & 0.40 \\
\hline $\mathbf{R 4 0}$ & 175 & 120 & 810 & 1215 & 130 & 0.41 \\
\hline $\mathbf{R 5 0}$ & 145 & 150 & 794 & 1190 & 147 & 0.42 \\
\hline $\mathbf{R 6 0}$ & 115 & 180 & 786 & 1178 & 155 & 0.45 \\
\hline
\end{tabular}

\subsection{Test Procedure}

The Compressive Strength of $150 \times 150 \times 150 \mathrm{~mm}$ cube Specimens, Split Tensile Strength of 150 x $300 \mathrm{~mm}$
Cylinders and Center point loading of 100 x 100 x $500 \mathrm{~mm}$ Prism specimens(Figure 14) were obtained at 7, 28 and 90 ages in accordance with IS : 516-1959 Specifications [21]
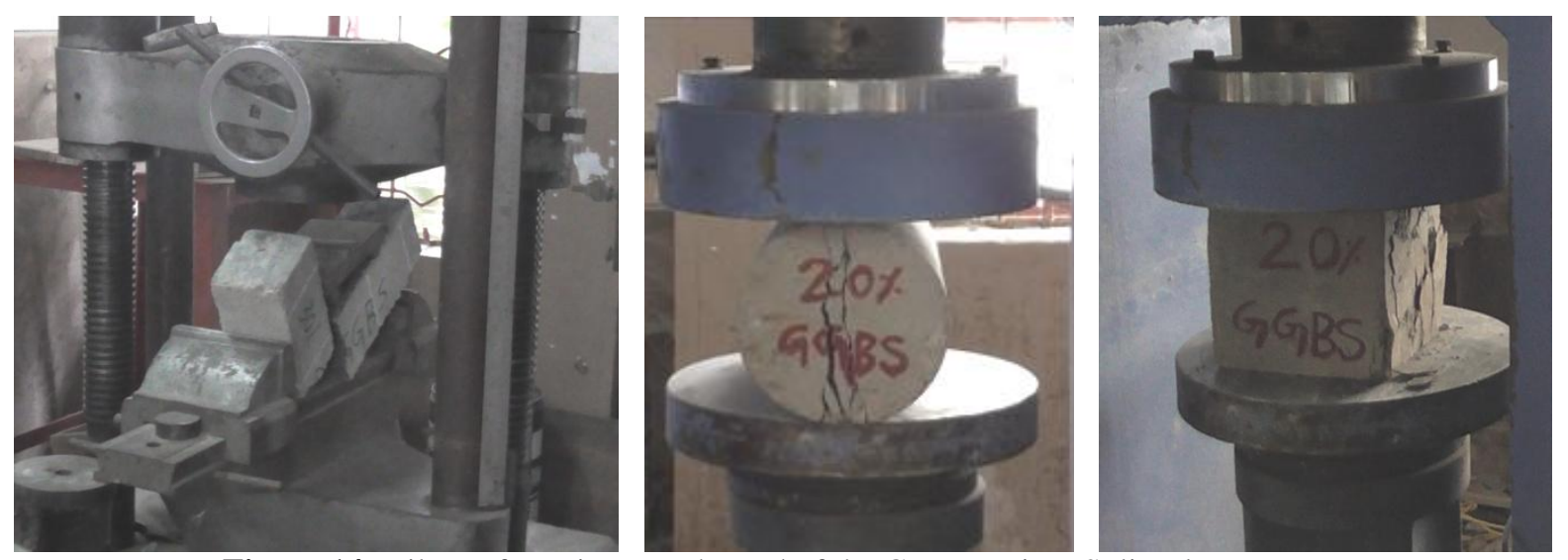

Figure.14 Failure of specimen at the end of the Compression, Split, Flexure tests 


\section{TEST RESULTS AND DISCUSSION}

The mechanical properties of the RCCP mixtures were presented in Table 7. It is observed that the minimum strength results at all ages are obtained at $60 \%$ GGBS level. This reduction in strength levels is higher at 7 day age specimens. This is due to the fact that the contribution of
GGBS to the strength of concrete is lower than that of cement at 28 days.

The relationship between GGBS content and strength of the mixtures are plotted in Figures 15 to 17 . As it can be observed from the figures, increasing the GGBS content caused increase in strength up to $10 \%$ replacement level.

Table 7: Compressive, Splitting Tensile and Flexural Strength Results (MPa)

\begin{tabular}{|c|c|c|c|c|c|c|c|c|c|c|c|c|}
\hline \multirow[t]{2}{*}{ Mix } & \multicolumn{4}{|c|}{ Compressive Strength(MPa) } & \multicolumn{4}{|c|}{ Split Tensile Strength(MPa) } & \multicolumn{4}{|c|}{ Flexural Strength (MPa) } \\
\hline & $3-d$ & $7-d$ & $28-d$ & $90-d$ & $3-d$ & $7-d$ & $28-d$ & $90-d$ & $3-d$ & $7-d$ & $28-d$ & $90-d$ \\
\hline $\mathbf{R 0}$ & 18.67 & 22.22 & 33.74 & 45.2 & 2.55 & 3.12 & 5.11 & 7.01 & 3.8 & 4.4 & 6.8 & 8.6 \\
\hline R10 & 17.5 & 29.9 & 45.22 & 52.11 & 1.97 & 3.41 & 5.27 & 7.23 & 3.12 & 4.88 & 7.58 & 8.89 \\
\hline $\mathbf{R} 20$ & 15.1 & 30.11 & 45.98 & 53.55 & 1.81 & 3.57 & 5.45 & 7.45 & 2.86 & 5.05 & 7.66 & 9.12 \\
\hline $\mathbf{R 3 0}$ & 14.8 & 32.02 & 46.21 & 56.90 & 1.64 & 3.88 & 5.75 & 8.78 & 2.78 & 5.23 & 7.97 & 9.34 \\
\hline R40 & 14.1 & 34.50 & 47.10 & 59.56 & 1.44 & 3.94 & 5.86 & 8.90 & 2.45 & 5.38 & 8.25 & 9.56 \\
\hline R50 & 13.8 & 34.02 & 46.31 & 57.41 & 1.27 & 3.78 & 5.62 & 8.58 & 2.11 & 5.24 & 7.98 & 9.44 \\
\hline R60 & 11.40 & 33.41 & 45.12 & 55.71 & 1.12 & 3.66 & 5.44 & 8.41 & 1.97 & 5.02 & 7.64 & 9.35 \\
\hline
\end{tabular}

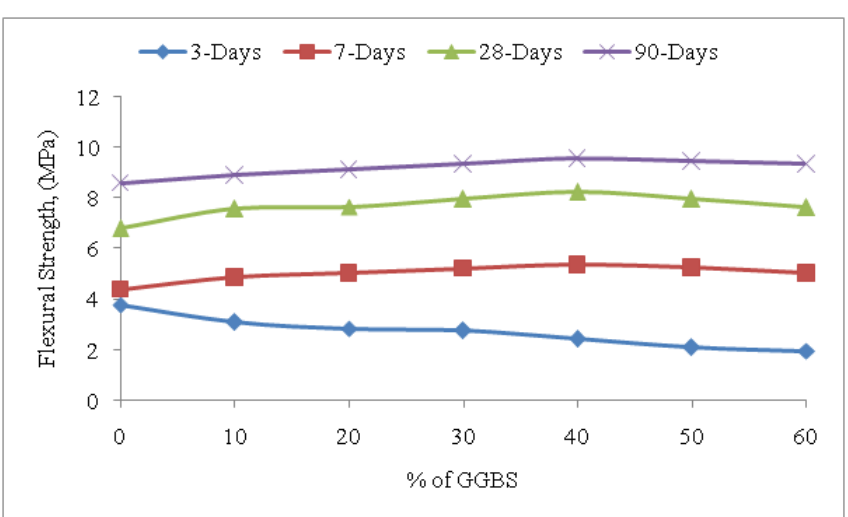

Figure.15 Variation of flexural strength with \% GGBS

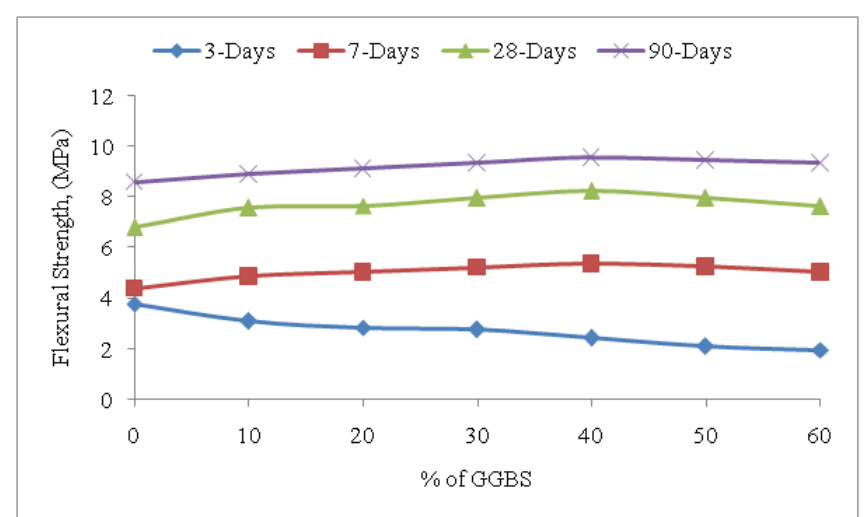

Figure.16 Variation of Compressive strength with \% GGBS

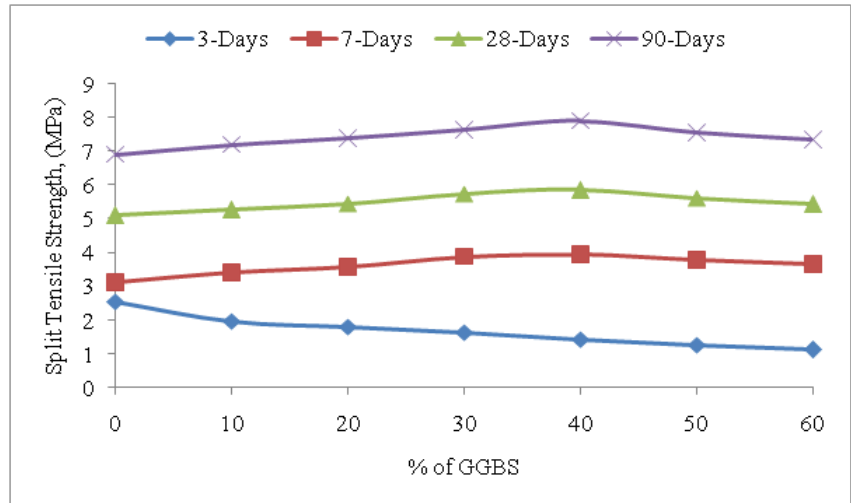

Figure.17 Variation of Split tensile strength with \% GGBS

\section{CONCLUSIONS}

From the experimental work, following conclusions were drawn:

1. The Optimum moisture content of the GGBS mixtures is increased with increase in GGBS content when compared to those of control mixtures

2. The maximum dry density is increased with increase in GGBS content up to $30 \%$ replacement level.

3. When cement was partially replaced with GGBS, strength values were increased with increase in GGBS content at 28 days and 90 days of curing. At early ages of 3 days, 7 days these strength values are lower than control mix due to the slow pozzolanic reaction of GGBS at younger age of concrete.

\section{REFERENCES}

[1] Atiş, C. D. (2005). Strength properties of high-volume GGBS roller compacted and workable concrete, and influence of curing condition. Cement and Concrete Research, 35(6), 1112-1121. 
[2] Yerramala, A., \& Babu, K. G. (2011). Transport properties of high volume GGBS roller compacted concrete. Cement and Concrete Composites, 33(10), 10571062.

[3] Cao, C., Sun, W., \& Qin, H. (2000). The analysis on strength and GGBS effect of roller-compacted concrete with high volume GGBS. Cement and concrete research, 30(1), 71-75.

[4] Courard, Luc, Frédéric Michel, and Pascal Delhez. "Use of concrete road recycled aggregates for roller compacted concrete." Construction and Building Materials 24.3 (2010): 390-395.

[5] Siddique, Rafat. "Effect of fine aggregate replacement with Class F fly ash on the mechanical properties of concrete." Cement and Concrete research 33.4 (2003): 539547.

[6] Madhkhan, M., R. Azizkhani, and ME Torki Harchegani. "Effects of pozzolans together with steel and polypropylene fibers on mechanical properties of RCC pavements." Construction and Building Materials 26.1 (2012): 102-112.

[7] Li, Beixing, Guoju Ke, and Mingkai Zhou. "Influence of manufactured sand characteristics on strength and abrasion resistance of pavement cement concrete." Construction and Building Materials 25.10 (2011): 3849-3853.

[8] Babu, K. Ganesh, and V. Sree Rama Kumar. "Efficiency of GGBS in concrete."Cement and Concrete Research 30.7 (2000): 1031-1036.

[9] Karimpour, A. "Effect of time span between mixing and compacting on roller compacted concrete (RCC) containing ground granulated blast furnace slag (GGBFS)." Construction and Building Materials 24.11 (2010): 2079-2083.

[10] Oner, A., and S. Akyuz. "An experimental study on optimum usage of GGBS for the compressive strength of concrete." Cement and Concrete Composites 29.6 (2007): 505-514.

[11] IS 12269-2013 Indian Standard Ordinary Portland Cement, 53 Grade - Specification ( First Revision )

[12] IS 4031 Methods of physical tests for hydraulic cement

[13] IS 383-1970 "Indian Standard specification for coarse and fine aggregates from natural sources for concrete (Second Revision)"

[14] ACI 211 3R-02, Guide for Selecting Proportions for No-Slump Concrete, 2002

[15] ACI 325 10R-95,state-of-the-Art report on roller compacted concrete pavements, ACI manual of concrete practice, ACI,USA, 2000:32PP

[16] Pavan, S., \& Rao, S. K. Effect of GGBS on Strength Characteristics of Roller Compacted Concrete Pavement. IOSR Journal of Mechanical and Civil Engineering (IOSRJMCE) Volume 11, Issue 6 Ver. II (Nov- Dec. 2014), PP 0408

[17].S.Krishna Rao, P.Sarika, P.Sravana, T.Chandra Sekhara Rao, Evaluation of Properties of roller compacted concrete Pavement, International Journal of Education and Applied Research, ISSN:2348-0033, Vol.4, Issue Spl-2, JAN-JUNE 2014

[18]. S.Krishna Rao, Dr.T.Chandra Sekhara Rao, Dr.P.Sravana, International Journal of Engineering Research and Technology, ISSN: 2278-0181, Vol.2, Issue2, February2013.

[19]. S.Krishna Rao, Dr.T.Chandra Sekhara Rao, Dr. P.Sravana, "Mix Design of Roller Compacted Concrete: An experimental study Using Crushed Stone \& River Sand as Fine Aggregate", National Conference on SCMAT, NIT Warangal, 2013.

[20] IS: 2720 (Part 8) - 1983. Determination of water content - dry density relation using heavy compaction, Bureau of Indian Standards

[21] IS: 516-1959, Indian standard code of practice Methods of test for strength of concrete, Bureau of Indian Standards, New Delhi, India. 